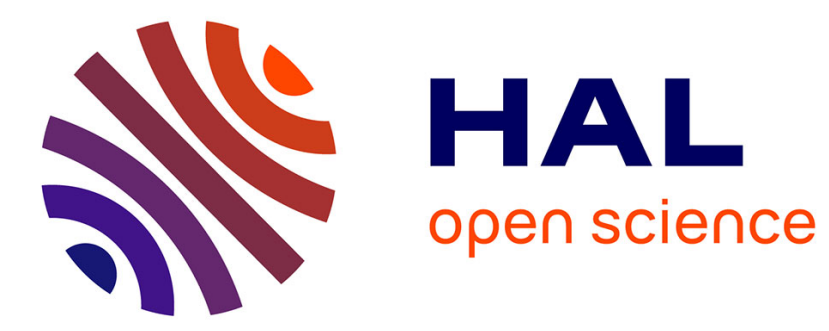

\title{
Chemiluminescence response of human neutrophils to He-Ne laser irradiation (in vivo and in vitro)
}

\author{
I. Schepetkin, V. Udut, A. Karpov
}

\section{To cite this version:}

I. Schepetkin, V. Udut, A. Karpov. Chemiluminescence response of human neutrophils to He-Ne laser irradiation (in vivo and in vitro). Journal de Physique IV Proceedings, 1994, 04 (C4), pp.C4-219-C4229. 10.1051/jp4:1994452 . jpa-00252715

\section{HAL Id: jpa-00252715 https://hal.science/jpa-00252715}

Submitted on 1 Jan 1994

HAL is a multi-disciplinary open access archive for the deposit and dissemination of scientific research documents, whether they are published or not. The documents may come from teaching and research institutions in France or abroad, or from public or private research centers.
L'archive ouverte pluridisciplinaire HAL, est destinée au dépôt et à la diffusion de documents scientifiques de niveau recherche, publiés ou non, émanant des établissements d'enseignement et de recherche français ou étrangers, des laboratoires publics ou privés. 


\title{
Chemiluminescence response of human neutrophils to He-Ne laser irradiation (in vivo and in vitro)
}

\author{
I.A. SCHEPETKIN, V.V. UDUT and A.B. KARPOV
}

Oncology Research Institute of the Russian Academy of Medical Sciences, Tomsk. 634001, Russia

\begin{abstract}
.
$\mathrm{He}-\mathrm{Ne}$ laser irradiation $\left(0.01-6 \mathrm{~J} / \mathrm{cm}^{3}\right)$ of the blood and neutrophile suspension in vitrowas shown to modulate reactive oxygen species (ROS) production in healthy donors. Intravascular laser irradiation of the blood $(5 \mathrm{mw}, 30$ minutes, daily) of the patients with chronic gastric ulcer during first 5 days resulted in increasing stimul-induced ROS production in patients with the low initial chemiluminescence response and its decreasing in patients with the high initial chemiluminescence response.
\end{abstract}

Key words: He-Ne laser, chemiluminescence, reactive oxygen species, neutrophils.

\section{Introduction}

The strong and growing interest in studying of mechanisms of the low-energy laser irradiation action on inflammation-related functions of phagocytio cells has been marked during recent years. In part, have shown that $\mathrm{N}_{2}$ laser $(\underline{\lambda}=337.1 \mathrm{~nm})\left({ }^{1}\right)$, He-Ne Iaser $(\underline{\lambda}=532.8 \mathrm{~nm})\left({ }^{2}\right)$, pulsed dye laser $(\underline{\lambda}=534-558 \mathrm{~nm})\left({ }^{1}\right)$, Ruby Iaser $(\lambda=$ $694.3 \mathrm{~nm})\left({ }^{3}\right)$ and infrared GaAlAs laser $(\lambda=820 \mathrm{~nm})\left({ }^{4}\right)$ can modulated the phagocytosis of particles and production of 
reactive oxygen species (ROS) by leukocytes and splenocytes. On the other hand, during the last decade, numerous reports have outlined the techniques and treatment results in patients with different diseases treated with these lasers $(5,6)$. Earlier, we have found the alteration of monocyte and neutrophils inflammation mediator profile (Tumor Necrosis Factor-a and ROS) in patients with gastric ulcer $\left({ }^{7}, 8\right)$. Intravascular irradiation of the blood by the He-Ne laser is successfully used for treatment of this disease $\left({ }^{9}\right)$. Here we address a question, whether the in vitro and in vivo He-Ne laser irradiation influences on neutrophile functions (ROS production) in the healthy donors and gastric ulcer patients.

\section{Materials and methods.}

A group of sixteen subjects aged from 30 to 45 years has been studied: 10 healthy donors (mans) and 6 patients with chronic gastric ulcer (both sexes). All diagnoses were confirmed gastroscopically. The patients did not receive any drugs before or during the study. The source of light was a He-Ne laser (model IG-92, Rugsia), $5 \mathrm{~mW}$ in output power on the end of the Iigh-conductor. The intravascular laser blood irradiation during daily with the exposure 30 minutes (ligh-conductor in cubital vein) 5 days were performed $\left({ }^{10}\right)$. Blood was received by venepuncture performed before and after intravascular irradiation between 09:00 hours and 11:00 hours.

Neutrophils were isolated from heparinized blood 110 $\mathrm{U} / \mathrm{ml}$ ) by centrifugation at $800 \mathrm{~g}$ for $30 \mathrm{~min}$ on a discontinuous Ficoll/Verografin gradient $(1.077 \mathrm{~g} / \mathrm{ml}$ and $1.119 \mathrm{~g} / \mathrm{mI}$ ) and were suspended in Hanks, balanced salt solution for $30 \mathrm{~min}$ at $25^{\circ} \mathrm{C}$ before being used. There were 
about $90 \%$ neutrophils in the cell suspension; their viability, assessed by trypan blue exclusion, was more than $96 \%$.

For in vitro irradiation, a blood was diluted by Hanks, balanced salt solution in ratio 1:10. A Iuminometrical test-tubes with a bottom diameter of $9 \mathrm{~mm}$ was filled with 1 $\mathrm{ml}$ of dilution blood or cell suspension. Irradiation of samples were performed in measuring chamber of Luminometer 1251 between two mirror semispheres at $37^{\circ} \mathrm{C}$. The ligh-conductor was immersed into a test-tube on $1 / 2$ value of cell suspension and the cells were irradiated $2 \mathrm{sec}, 10 \mathrm{sec}$, $60 \mathrm{sec}, 5 \mathrm{~min}$ and $20 \mathrm{~min}\left(0.01,0.05,0.3,1.5\right.$ and $6 \mathrm{~J} / \mathrm{cm}^{3}$, respectively) at continuous mixer. As a control, $1 \mathrm{ml}$ aliquots at the same blood or neutrophil suspension were kept under the same conditions but was not irradiated.

The production of reactive oxygen species was determined chemiluminometrically immediatedly after the irradiation by using an automatic luminometer model 1251 (Wallao, Finland) at $37^{\circ} \mathrm{C}$ in the presence of Iuminol (Sigma, USA) as was described previousiy $\left({ }^{7}\right)$. Briefly, $100 \mu 1$ luminol, to the final concentration of $25 \mu \mathrm{M}$, was added to $800 \mu \mathrm{I}$ dilution blood or neutrophil suspension containing $4 \times 10^{5}$ cells in a test-tube. After measuring the spontaneous chemiluminescence (CL) (15 min) $100 \mu \mathrm{I}$ calcium ionophore A23187 (Sigma, USA) (final concentration $=1 \mu \mathrm{M}$ ) or $100 \mu \mathrm{I}$ activator of protein kinase C - phorbo1-12-myristate-13-acetate (PMA) (Sigma, USA) ( $\mathrm{final}$ concentration $=10 \mathrm{nM}$ ) was added to the test-tube and the CI was registered for $60 \mathrm{~min}$.

The data obtained were analysed by using the LUMOGRAF program on an IBM-PO computer $\left({ }^{11}\right)$. To estimate PMA- and A23187- induced CI the following coefficients were calculated: 


$$
\begin{aligned}
& c_{P M A}=\left(\int_{0}^{60} I_{P M A}-\int_{0}^{60} I_{S C L}\right) / \int_{0}^{60} I_{S C L}, \\
& c_{A 23187}=\left(\int_{0}^{60} I_{A 23187}-\int_{0}^{60} I_{S C L}\right) / \int_{0}^{60} I_{S C L} .
\end{aligned}
$$

where $\int_{0}^{60} I_{\mathrm{PMA}}, \int_{0}^{60} I_{\mathrm{A} 2387}$ and $\int_{0}^{60} I_{\mathrm{SCL}}$ are integral for $60 \mathrm{~min}$ of the chemiluminescence response in presence of PMA (or A23187) and Henks' solution (spontaneous CL), respectively. The effeot of laser irradiation was estimated as ratio integral value of spontaneous or induced chemiluminescence to control (nonirradiated) samples CI.

\section{Results.}

In the first series of experiments the influenoe of laser irradiation on the blood CL was studied. It was shown that laser irradiation aotivate spontaneous CI in the blood of healthy donors (table). This activation influence was more expressive at the first minutes after irradiation, what conform with data, obtained by Karu et al. for He-Ne laserlaser-induced CI response of splenocytes $\left({ }^{2}\right)$.

The final effect of the laser irradiation on PMA-induced CI was depended on the initial values of stimulated oL $\left(C_{\text {PMA }}\right)$. In lact, we may divided examinated sample to three groups, according to the $C_{P M A}$ value: (1) activation of the CI-response by irradiation (dose-dependent effect was noted in the interval from 0.01 to $0.3 \mathrm{~J} / \mathrm{cm}^{3}$ ) (tree subjeots, $\left.C_{\text {PMA }}: 0.11,0.12,0.93\right) ;(2)$ the slight modulation of the CL-response by irradiation (dose-dependent effect was not shown) (five subjects, $C_{\mathrm{PMA}}: 1.1,1.7,4.0,5.4,7.3,8.0$ ); (3) irradiation caused decreasing of the CI-response (dose-dependent effect) (two subjects, $\mathrm{C}_{\mathrm{PMA}}: 1.1,5.4$ ). Thus, activating dose-dependent effect of irradiation was observed 
Table. The influence of He-Ne laser irradiation $\left(0.3 \mathrm{~J} / \mathrm{cm}^{3}\right)$ on CI response of human blood in heal thy subjects (\% control). Each meaning represent of triplicates. SCL - spontaneous CL. Level of significance: * $p<0.05$.

\begin{tabular}{lcccc}
\hline \multirow{2}{*}{ Subjects } & \multicolumn{2}{c|}{ SCL, integral for } & \multicolumn{2}{c}{ Induced CI } \\
& $15 \mathrm{~min}$ & $60 \mathrm{~min}$ & PKa, 10 nM & A23187, $1 \mathrm{MM}$ \\
\hline A & $127^{*}$ & 103 & $120^{*}$ & $113^{*}$ \\
B & $125^{*}$ & $114^{*}$ & $136^{*}$ & $422^{*}$ \\
C & $81^{*}$ & $88^{*}$ & 101 & $91^{*}$ \\
D & 97 & 98 & 107 & $116^{*}$ \\
E & $110^{*}$ & $111^{*}$ & $139^{*}$ & $96^{*}$ \\
F & $115^{*}$ & 108 & 97 & $112^{*}$ \\
G & $129^{*}$ & 105 & $151^{*}$ & $135^{*}$ \\
H & $133^{*}$ & $122^{*}$ & $91^{*}$ & $109^{*}$ \\
I & $137^{*}$ & $109^{*}$ & 105 & $111^{*}$ \\
J & $140^{*}$ & 103 & $120^{*}$ & $113^{*}$ \\
\hline
\end{tabular}

on low initial values of the PMA-induced CL $\left(C_{\mathrm{PMA}}<1\right)$.

When A23187-stimulated blood was irradiated, the dose-dependent action on CL was not obvious than in experiments with the PMA-induced blood. The groups structure In this series of experiments was differ from such to the PMA-induced CL.

Laser irradiation, in 50\% of cases (irradiation doses were 0.05 and $0.3 \mathrm{~J} / \mathrm{cm}^{3}$ ) was resulted in decreasing of time of reaching the highest CI value induced oxidative burst (A23187 or PMA) (Fig. 1, for PMA data is not shown). The 
kinetic curve of CL-response of neutrophils is dependent on the rate of myeloperoxidase release (12)It may be possible, that laser irradiation accelerate neutrophil degranulation process.

In the second series of experiments, we studied the irradiation effect on spontaneous and induced $\mathrm{CL}$ of neutrophils suspension. CeIIs irradiation (doses were 0.3 $0.6 \mathrm{~J} / \mathrm{cm}^{3}$ ) dose-dependently activated spontaneous $\mathrm{CL}$, and, practically, had no influence on PMA-induced CI ( $p>0.05$ ) (Fig. 2).

To research the intravasoular blood irradiation influence on neutrophils ROS production, we investigated. "Immediate" (measures of induced CI level was carried out at 15 min after irradiation) and "distant" (twenty-four hours after irradiation) effects. We found out, that intravasoular blood irradiation forced undulating alterations of PMA- or A23187- induced CI with gradual decreasing of fluctuations during 5 days of laserotherapy. Intravascular irradiation of the blood by $\mathrm{He}-\mathrm{Ne}$ laser on the next day after the first treatment resulted in increasing A23187-stimulated and PMA-induced CI in patients with the low initial CL-response 


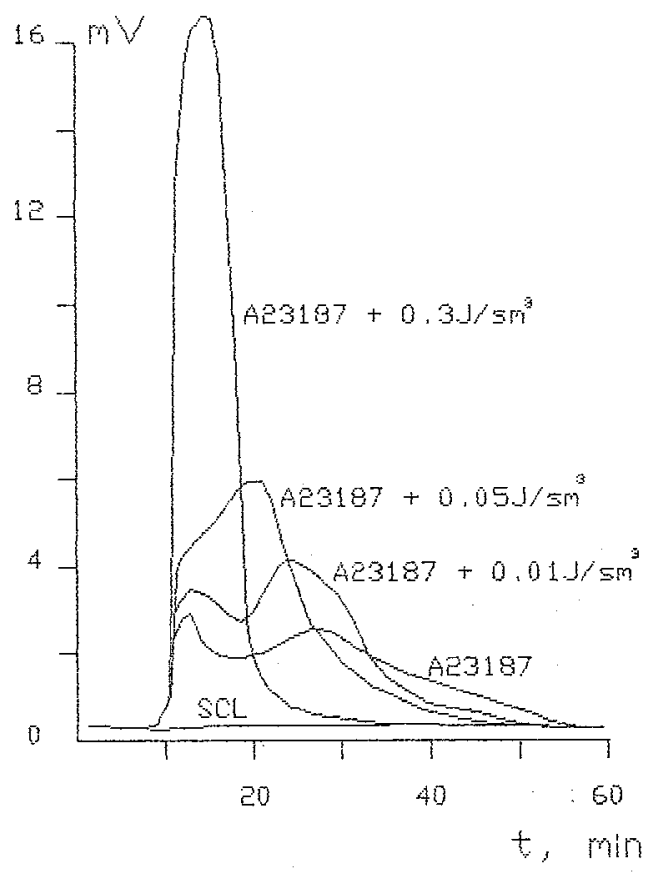

Fig. 1. The effect of He-Ne laser irradiation on the A23187induced blood CI in healthy subject (A23187 = $1 \mu \mathrm{M})$. SCL - spontaneous CI.

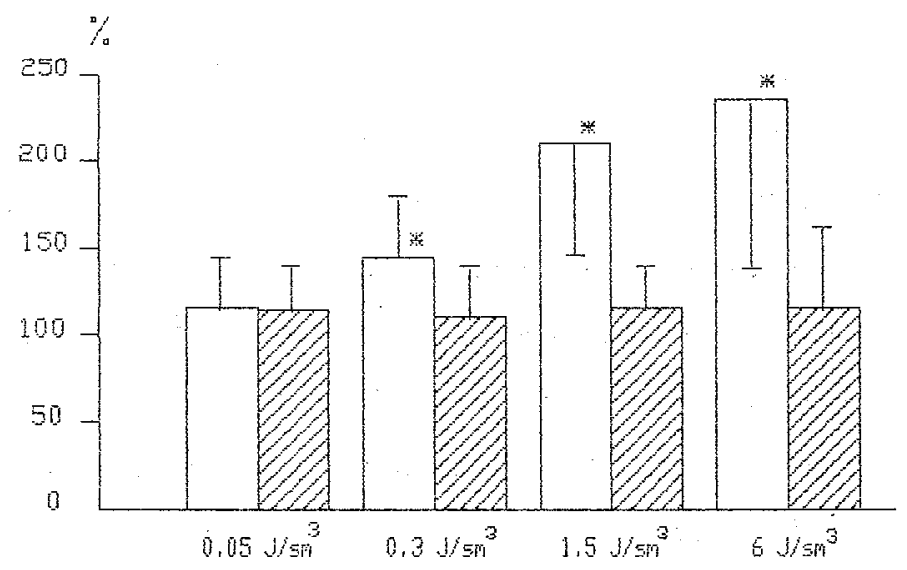

Fig. 2. The effect of He-Ne laser irradiation on neutrophils CL. (1) spontaneous CL; (2) PMA-induoed CI (PMA = 10nk). Each columns represent means of triple measuring of six healthy subjects. $\%$ cortrol.

Level of significance: * $\mathrm{p}<0.05$. 
and its decreasing in patients with the high initial CL-response. The average minimum value of A23187- and PMAinduced $\mathrm{Cr}$ was observed on third day (after two irradiation treatment) (Fig. 3). (for PKA-induced CL data is not shown). Comparisons of experiments in vivo and in vitro revealed that modulating "immediate" influence of the blood irradiation had similar results.

As we know, kinetios of luminol-dependent chemiluminescence of neurtophils is determinated by proceeding aotivity of following processes: neutrophils degramulation with myeloperoxidase release, Iuminol diffusion into the cells and its interaction with intracelIular-production ROS, activity of enzymes of formation and metabolism of reactionable elements, which interacted with luminol: membranoconnected $\mathrm{NADPH}_{2}$-oxidase, superoxide dismutase, catalase or myeloperoxidase $\left(^{12}\right)$. RealIy, $\mathrm{NADPH}_{2}-$ oxidase is a complicated multicomponent ferment complex and its activation can be proceeding similar with mechanism, proposed to explanation of activation effect of laser beam on flavin components of the respiratory chain (13). Activation influence of $\mathrm{He}-\mathrm{Ne}$ laser on catalase and superoxide dismutase was demonstrated too $(14,15)$. Although, in other works that fact was not confirm $\left({ }^{16}\right)$. On the other hand, the most of this processes is directiy connected with cellular membrane or with neutrophil intracellular lipids. Therefore, it is possible, that in the base of biostimulating influence of laser irradiation on neutrophils may be structure-functional recombinations of membrane elements with regulating orientation.

Thus, in our report was demonstrated, that laser irradiation (He-Ne laser, $\lambda=632.8 \mathrm{~nm}$ ) causes activation of 


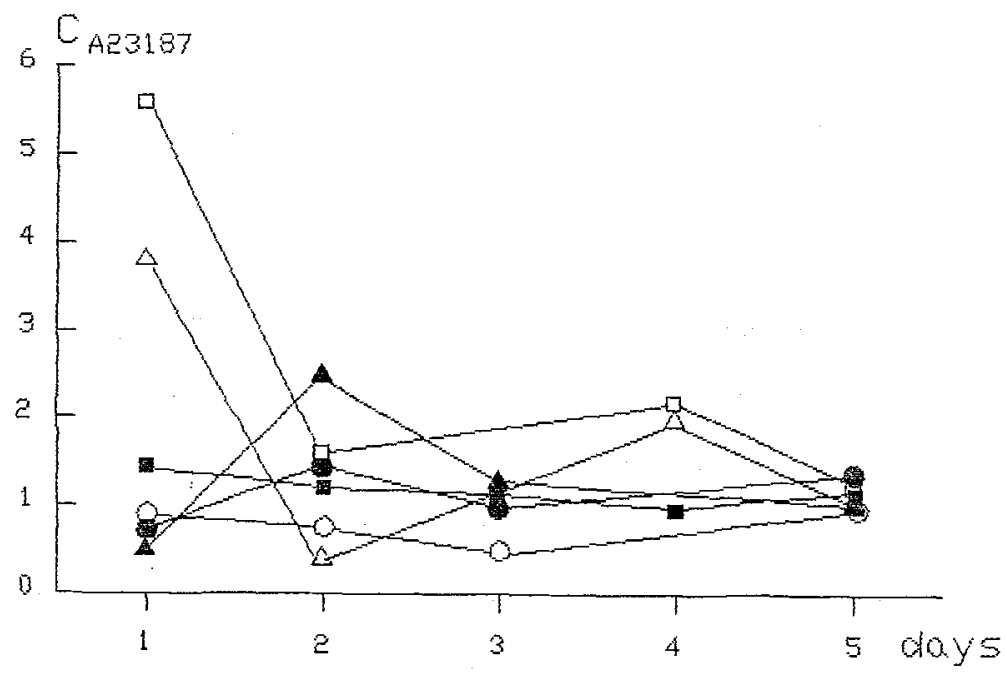

Fig. 3. The effect of intravascular He-Ne laser irradiation on the A23187-induced blood CL in six patients with gastric ulcer $(A 23187=1 \mu N)$. Each point represent of triplioates.

spontaneous ROS production by human neutrophils under irradiation, both in the blood and in the cells suspension. Based on our data, we may propose that the results of the blood irradiation, in vivo and in vitro, are dependent on intial values of induced CL, irradiation dose and, possible, on modulation influence of other blood cells. 


\section{RETHRENCES.}

1. Mester E., Kosma I., Dudas V. et al. Action of laser radiation on phagocytic activity of leukocytes // Doklady Akad. Nauk BSSR. 1979. VOI. 23. P. 749-752.

2. Karu T.I., Ryabykh T.P., Fedoseyeva G.E., Puchkova N.I. Heliumneon laser-induced respiratory burst of phagocytic cells // Lasers in Surg. Med. 1989. Vol. 9. P. 585-588.

3. Mester E., Iudany G., Vajda J. et al. Under die wirkung von Laser-Strahlen auf die Bakterienphagozytose der Leukozyten // Acta Biol. Med. Germ. 1968. Vol. 21. P. 317-321.

4. Andreichuk T.N., Karu T.I., Ryabykh T.P. Correlation between cellular composition of the spleen and changes in chemiluminescence of the splenocytes after laser irradiation // Bul1. Exp. Biol. Med. 1992. Vol. 114. P. 153-155.

5. Basford J.R. Low-energy laser therapy: controversies and new research findings // Lasers in Surg. Med. 1989. Vol. 9. P. 1-5.

6. Gamaleya N.F. Laser biomedical research in the USSR // Laser application in medicine and biology. V. 3. New York and Iondon: Plenum Press. Ed. by M. Molbarsht. 1977. P. 1-175.

7. Sohepetkin I.A., Cherdyncera N.V., Borunor E.V. et al. Decreased luminol-dependent chemiluminescence response of neutrophils to recombinant human tumor necrosis factor in patients with gastric cancer // J. Cancer Res. Clin. Oncol. 1991. Vol. 117. P. 172-174.

8. Schepetkin I.A., Volyntseva I.B., Borunov E.V. et al. The alteration of monocyte cytotoxic mediator profile in patients with gastric cancer and precancer gastric disease // Bull. Exp. Biol. Med. 1991. Vol. 111. P. 175-177. 
9. Sazonov A.M., Romanov G.A., Portnoy I.M. et al. Using the lowpower noncogerent red beam in compexis treatment of gastrio and duodenal ulcer // Sov. medicine. 1985. N 12. P. 42-46.

10. Udut V.V., Prokopjev V.E., Karpor A.B. et al. Mechanisms and effects of low energy He-Ne lasers radiation on circulating blood // J. de Physique IV. 1991. Colloque C7, suppl. III. VoI. 1. P. 257-260.

11. Borunov E.V., Schepetkin I.A., Cherdyntcev E.S., Cherdyntceva N.V. // Neutrophil chemiluminescence with the use of the IUMINOMETER-1251 device and the LUMOGRAF program. Clin. Lab. Diagn. 1993. N 3. P. 13-16.

12. Anianson H., Stendahl 0., DahIgren C. // Acta Pathol. Microbiol. Immunol. Scand. 1984. Vol. 92. P. 357-361.

13. Karu T. Photobiology of Iow-power laser effeots // Health Phisios. 1989. Vol. 56. P. 691-704.

14. Gorbatenkova E.A., Vladimirov Yu.A., Paramonov N.V., Azizova $0 . A$. The red light of helium-neon laser reactivated superoxide dismutase // Bull. Exp. Biol. Med. 1989. Vol. 107. P. 302-305.

15. Romm A.R., Sherstnev M.P., Volkov V.I., Vladimirov Yu.A. The effect of laser radiation on peroxide chemiluminescence of wound tissue fluid // Bull. Exp. Blol. Med. 1986. Vol. 102. P. 426-428.

16. Fedoseyeva G.E., Karu T.I., Iyapunova T.S. et al. The effect of low-intensity red light on the activity of yeast enzymes. Microbiologiya. 1986. Vol. 55. P. 944-948. 